\title{
A comparative analysis of green logistic activities in German and Turkish textile enterprises
}

DOI: $10.35530 / I T .072 .01 .1681$

\section{ABSTRACT - REZUMAT}

\section{A comparative analysis of green logistic activities in German and Turkish textile enterprises}

The main goal of this research is to find out what are the apparel industry activities in the face of green perspective (environment-friendly perspective) in Germany and Turkey. The green perspective is an emerging idea and also has importance for the humanity and the universe. However it is obvious that the green perspective is very broad, it was decided to make this research in the field of supply chain management and the place of logistics in supply chain under the title of green perspective. In this context, a survey, face-to-face interviews were made with professionals in Germany and Turkey. These professionals were the managers who are taking part in the supply chain. In the conclusion part, German and Turkish companies' activities in the face of green perspective under the title of logistics were compared and evaluated.

Keywords: green logistics, comparative analysis, Germany and Turkey, apparel industry

\section{O analiză comparativă a activităților logistice ecologice în întreprinderile textile din Germania și Turcia}

Scopul principal al acestei cercetări este de a analiza activitățile industriei de îmbrăcăminte în contextul unei perspective ecologice în Germania și Turcia. Perspectiva ecologică este o idee emergentă și are, de asemenea, importanță pentru umanitate și univers. Cu toate acestea, este evident că perspectiva ecologică este foarte vastă și s-a decis efectuarea acestei cercetări în domeniul gestionării lanțului de aprovizionare și a locului logisticii în lanțul de aprovizionare, din perspectiva ecologică. În acest context, au fost realizate un sondaj și interviuri față în față cu profesioniști din Germania și din Turcia. Acești profesioniști au fost managerii care participă la lanțul de aprovizionare. În partea de încheiere, au fost comparate și evaluate activitățile companiilor germane și turcești în fața unei perspective ecologice ale logisticii.

Cuvinte-cheie: logistică ecologică, analiză comparativă, Germania și Turcia, industria de îmbrăcăminte

\section{INTRODUCTION}

In daily stories of record temperatures, extreme weather, floods and droughts, and of renewable energy, carbon footprints, recycling and energy efficiency, the environment is increasingly becoming headline news. Governments are moving slowly towards new international agreements that will start to address the impact of business on the environment, and these, undoubtedly, will place new requirements on every organization. Consumers expect every business to take responsibility for its actions to look at the way it operates and measure their environmental impact, then determine a strategy to reduce it (figure 1).

According to McKinnon et al. [2], green logistic activities include measuring the environmental impact of different transportation strategies, reducing the energy usage in logistic activities, reducing waste and managing its treatment. In recent years there has been increasing concern about the environmental effects on the planet of human activity and current logistics practices may not be sustainable in the long term. Many organizations and businesses are starting to measure their carbon footprints so that the

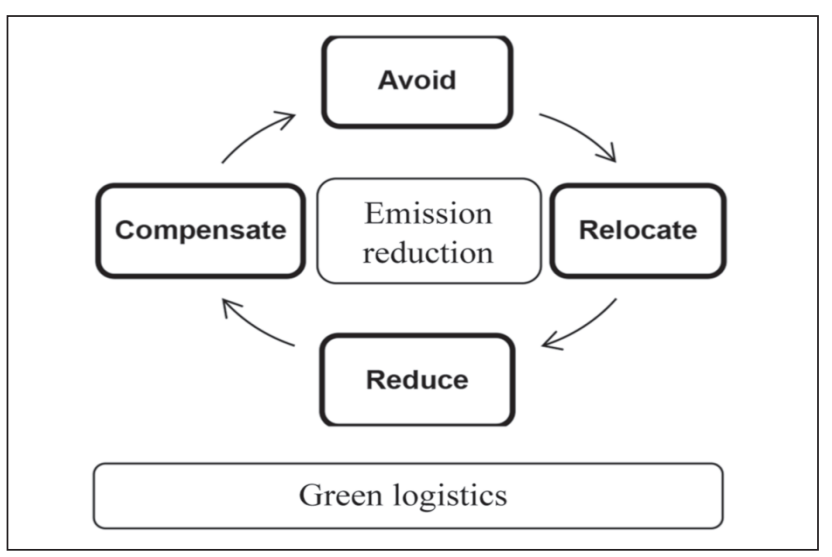

Fig. 1. Green Logistics Cycle [1]

environmental impact of their activities can be monitored. Governments are considering targets for reduced emissions and other environmental measures. For this reason, there is increasing interest in green logistics from governments, companies, customers and also consumers.

Küçük [3] mentioned that especially in fashion industry, the ability to respond customer requirements on a 
timely basis has always been a fundamental element of the marketing concept. "Time-based competition" has become the norm in many markets, from banking to automobiles, also fashion.

According to Christopher and Peck [4], nowhere is this pressure more evident than in markets governed by fashion. "Fashion" is a broad term that typically encompasses any product or market where there is an element of style that is likely to be short-lived. Christopher and Peck [4] have defined apparel industry as typically exhibiting the following characteristics:

- Short lifecycles; The product is often ephemeral, designed to capture the mood of the moment; consequently the period in which it is saleable is likely to be very short and seasonal, measured in months or even weeks.

- High volatility; Demand for these products is rarely stable or linear. It may be influenced by the vagaries of weather, hit films, TV shows or even by pop stars and footballers.

- Low predictability; Because of the volatility of demand it is extremely difficult to forecast with any accuracy even total demand during a period, let alone week-by-week or item-by-item demand.

- High impulse purchase; Many buying decisions for these products are made at the point of purchase. In other words, the shopper when confronted with the product is stimulated to buy it, hence the critical role of "availability" and, in particular, availability of sizes, colors, etc.

In 2012, Sarkar investigated the potent tools for sustainable green marketing [5]. The article analyzed different dimensions and facets of green supply chain management, including the evolution of the concept, implementation strategy, linkage with transport systems, green innovations and sustainability issues and green logistics strategies for evolving integrated green supply chain management system.

In another study held in 2013, Perera et al. [6], attempt to quantify the environmental performance of supply chain of a manufacturing company. They used multi-criteria decision method for measuring the per- formance of the criteria that they determined. In the conclusion the proposed model was applied to a case study company to identify the key areas of environmental performance of the company's supply chain and to assess various product categories manufactured under those key areas.

Batra et al., in 2015 [7], made a research on greening the supply chain. They reviewed the literature on green supply chain \& steps to be taken by the enterprises to achieve social, environmental \& economic benefits.

Abdullah et al., in 2016 [8], investigated the involvement of Third Party Logistics (3PL) companies in applying Green Logistics initiatives in the event of rendering logistics services to its customers. They implemented this study in Malesia and utilized Malesia's terms and conditions only.

In a study from 2017 by Desore and Narula [9], they review today's literature related to sustainability issues of the textile industry for all over the world. The authors categorize the literature to discuss the drivers, barriers, and responses of firms in the textile industry in favor of sustainability.

The goal of a study by Gardas et al., in 2018 [10], is to identify the critical challenges to sustainable development in the textile and clothing sector. In this concept, fourteen critical points about the sustainable development of the textile and clothing sector were identified and a survey and their cause-effect relationship was determined using the DEMATEL method.

Samar Ali et al. in 2019 [11] was made a study about green practices in manufacturing sector and this study aimed to discriminate the sustainable and competitive performance of the Indian manufacturing sector and to comprehend the degree of the impact of green practices of supply chain management.

Table 1 was prepared by taking into account the 6 main criteria (1 - Activities of customs administrations, 2 - Infrastructure, 3 - International transportation fee, 4 - Quality of logistic services, 5 - Punctuality of cargo transportation, 6 - Tracking possibility of cargoes) for evaluating the 160 countries' logistics

Table 1

\begin{tabular}{|c|c|c|c|c|c|c|c|}
\hline \multicolumn{7}{|c|}{ LOGISTICS PERFORMANCE INDEX (LPI) RANK 2018 [12] } \\
\hline Country & LPI rank & LPI score & Customs & Infrastructure & $\begin{array}{c}\text { Logistics } \\
\text { competence }\end{array}$ & $\begin{array}{c}\text { Tracking \& } \\
\text { tracing }\end{array}$ & Timeliness \\
\hline Germany & 1 & 4.20 & 4.09 & 4.37 & 4.31 & 4.24 & 4.39 \\
\hline Sweden & 2 & 4.05 & 4.05 & 4.24 & 3.98 & 3.88 & 4.28 \\
\hline Belgium & 3 & 4.04 & 3.66 & 3.98 & 4.13 & 4.05 & 4.41 \\
\hline Austria & 4 & 4.03 & 3.71 & 4.18 & 4.08 & 4.09 & 4.25 \\
\hline Japan & 5 & 4.03 & 3.99 & 4.25 & 4.09 & 4.05 & 4.25 \\
\hline Netherlands & 6 & 4.02 & 3.92 & 4.21 & 4.09 & 4.02 & 4.25 \\
\hline Oman & 43 & 3.20 & 2.87 & 3.16 & 3.05 & 2.97 & 3.80 \\
\hline India & 44 & 3.18 & 2.96 & 2.91 & 3.13 & 3.32 & 3.50 \\
\hline Cyprus & 45 & 3.15 & 3.05 & 2.89 & 3.00 & 3.15 & 3.62 \\
\hline Indonesia & 46 & 3.15 & 2.67 & 2.89 & 3.10 & 3.30 & 3.67 \\
\hline Turkey & 47 & 3.15 & 2.71 & 3.21 & 3.05 & 3.23 & 3.63 \\
\hline
\end{tabular}


performance. According to this index while Germany is in the 1 st place, Turkey is $47^{\text {th }}$.

The purpose of this study is to find out how are the real explanations of some hypothesis and also the comparison of Turkish and German companies' relevant activities. The first hypothesis is to determine the role of logistics in supply chain management. It affects the customer satisfaction and total cost reduction, as well as company profitability. This is particularly significant as companies are increasingly being driven by the goal of enhancing shareholder value, a key measure of corporate performance. The second is to determine the role of companies' social and environmental responsibility. The last hypothesis is to compare Turkish and German companies' relevant activities in the face of green perspective under the title of logistics.

Moreover, this study is giving a raft of options, suggestions and concrete advice on how to go green on logistics department in the apparel industry. It includes some interviews with the professional managers from Turkish and German companies. Although many of previous articles describe general topics in logistics or supply chain, this study would like to mention the environmental impact of logistics and supply chain under the consideration of sustainable aspects for apparel industry.

Most analyzed previous studies are descriptive on a national basis. In the literature, the studies based on green logistic activity in textile and apparel industry areas are limited. Especially there is no comparison of Turkey and Germany. Therefore, it is intended to fill this gap. For instance, the studies below have done recently in the literature about the green logistics.

\section{MATERIAL AND METHOD}

\section{Material}

This study is held as a comparative research of Turkish and German apparel companies, the material consists of 6 different Turkish and 6 different German apparel companies and their logistical activities.

\section{Method}

In this research which compares the environmental sensibility of logistics activities of the apparel companies in Turkey and Germany, the qualitative research method was used to reveal the similarities and strength and weaknesses of the companies.

The "Qualitative Research Method" was chosen during writing and assessing this research study. The qualitative method involves the gathering of a lot of information from few examination units through interviews and observations. There are three most common qualitative methods which are participant observation, in-depth interviews, and focus groups. Each method is particularly suited for obtaining a specific type of data.

- Participant observation; is appropriate for collecting data on naturally occurring behaviors in their usual contexts.

- In-depth interviews; are optimal for collecting data on individuals' personal histories, perspectives, and experiences, particularly when sensitive topics are being explored.

- Focus groups; are effective in eliciting data on the cultural norms of a group and in generating broad overviews of issues of concern to the cultural groups or subgroups represented [13].

From those methods, the most useful and impressive one was decided to use for this study; in-depth interviews. So the plan was to make some interviews with professional managers and perceive their point of views and opinions.

The interview is an effective method of collecting information for certain types of research questions and for addressing certain types of assumptions. There are two types of interviews: structured and semi-structured interviews. The choice depends on what the research topic is. In structured interviews, formally structured - without any adjustment and additional questions - and the same questions are asked to all of the respondents, whereas in semistructured interviews, wordings, the level of language and the order of questions are flexible and may be adjusted. There may be also additional questions followed up [13].

Considering the different types of interviews and the research goals of this study, the "structured interview" type was decided to use. The reason of selecting the structured interview is to evaluate all companies equally. There were no adjusted questions or deviations varying from company to company.

Sampling

The samples of this study were selected upon purposive sampling. It was stated by Given [14] that purposive sampling is virtually synonymous with qualitative research. Purposive sampling is explained as: "It is one of the most common sampling strategies according to a criterion relevant to particular research questions. Furthermore, sample size may or may not be fixed prior to data collection, depend on the resources and time available, as well as the study objectives. Purposive sampling is accepted to be the most successful when data review and analysis are done in conjunction with data collection" [15].

The selected companies in the scope of the study are large-scale companies which have activities and investments in the field of textile and apparel logistics in Turkey and Germany. Responses were received via face-to-face and/or telephone interviews. However, 9 companies from Turkey and 10 companies from Germany were selected, the responses were collected hardly from 6 Turkish and 6 German companies.

Data Collection Method: Interviews

A survey was decided to conduct with Turkish and German apparel companies to evaluate the research questions. This survey would be like a short-interview with the companies' managers. In this interview, some questions were determined and would be asked.

During the preparation of these questions, the intent was to get direct, concrete and assessment-easy answers. For that reason; the questions which are shown below were prepared and asked. 
Interview questions:

1. What do you think as a company about Green Perspective?

2. The main objective is to make money in the business but it is obvious that the process of Green Application requires some investments which mean additional cost. Could you please explain your standpoint according to this economical aspect?

3. Have you ever applied on Green Process for any departments of your company? If no, are you planning to do and in which department? If yes, when?

4. Do you really think that logistics should be environmentally friendly first? Or, are there some other departments which are more important and have priority on logistics?

5. What do you think about the environmental effect of logistics?

6. Do you think that your company has a productive logistical management system by the ecological point of view?

7. Do you take any precautions against your possible environmental effects of warehousing such as waste, package plastic and etc.? For example do you use recycled material?

8. Do you have as a company your own "Code of Conducts" about logistics?

9. Is it important for your company to determine your supplier to consider the environmental policy of their government/country?

10. How does the government act in the face of green perspective in Germany/Turkey? Is there any governmental inducement/obligation to improve your environment policy on green logistics?

\section{Data Assessment Titles}

In order to make the assessment more concrete, the questions were classified among themselves and titles which belong to each classes were identified. The evaluation of the answers collected from the companies, is in the form of the answers being classified under the titles below. Accordingly, the determined titles and the questions are:

- Green perspective and the industry: Question number 1

- Money or environment or both: Question number 2

- Until now...: Question number 3

- Precautions: Question number 7

- Supplier Selection and Environment: Question number 9

- Enough Governmental Inducements/Obligations: Question number 10

- Logistics \& Environment: Question number 4, 5, 6 and 8.

\section{FINDINGS}

This study is based on qualitative research. The questions and the answers which were obtained through the interviews were discussed separately. The following titles below were analyzed by thinking of the interviewers' answers.

\section{Green perspective and the industry}

Turkish case

The general idea in the direction of the answers taken from the companies is, the environmental awareness of the companies is in the front lines among the commercial activities. Companies' sustainability strategy within the framework of the sustainability approach combines in two focus areas: the environment and people. In order to continuously improvement in accordance with the aims and targets which were set by the companies. They:

- Observe the current environmental legislation and discharge the legal obligations,

- Exhibit sensitive and effective behaviors against the environmental pollution,

- Reduce all the emissions and wastes by implementing an effective waste management system,

- Always and regularly observing the environmental management systems.

Additionally Turkish companies stated that, the aim is to have an integrated approach on sustainability where they are able to turn potential sustainability risks into opportunities which ultimately benefit their environment and their company. These opportunities include; waste management, pollution prevention, carbon footprint reduction, water and energy efficiency/ production, and more efficient use of raw materials.

German case

During the interviews it was found out that, according to the ideas of the managers, the companies are more or less trying to do something good for the environment. For instance, they try to spread the warning that "do not print if not necessary" about printing. In their office and canteen, they split the rubbish into the categories of paper, plastic, glass and so on. Some of them have never heard the idea of green logistics and some of them have just comprehended the idea. It means, they do not think about the logistics part to do it green obviously.

However they have too much knowledge to do the production environmentally, it is also common that doing logistics green requires up-to-date information. There are no common activities with the logistics to do it green. According to the managers, until now, there have been a lot of studies, books, articles, materials also some workshops about the green production but not for green logistics. It is obvious that day-by-day some researchers in the industry, professors in the universities are doing a lot of research and process development. For that reason, in the production department besides products, the waste and the other things which are harmful for the environment are generated more than logistics department.

\section{Money or environment or both}

Turkish case

The general idea about this question is "The publicity of the social responsibility projects as such green applications, brings prestige and subsequently financial gain to the companies". Two companies among the all have the certificate of SA $8000, \mathrm{BSCl}$ (Business Social Compliance Initiative) Oekotex Standard 100, GOTS, OEKO-TEX STeP and OCS. 
The other one is a member of Climate Platform established by 'Turkish Industrialists' and Businessmen's Association (Tüsiad)" and "Regional Environmental Center (REC)". It is obvious that these companies consider both the environment and their monetary assets. However, it was understood after the interviews with the rest of the companies that they care about the environment in theory, but they do not so successful in practice.

German case

If companies decided to be sustainable on ecology, it directly increases the value and image of the company very positively, so it brings to companies better financial results, prestige and productivity. Also the environment gives back the positive answer: If humans protect the environment, it also protects the humans. They think that the investment in green process is return on investment. Managers are aware of the fact that, if some investments are made to be more environmental friendly, it brings more things than money like good customer relations, profit, a good reputation and so on. They think that it is very necessary to save the planet with some investments but the investment should end up with some profit. If it brings profit then they see this situation as „set a sprat to catch a mackerel". So they set the sprats. From the answers of this question it is obvious that they consider both, money and environment together.

\section{Until now...}

\section{Turkish case}

All of the interviewed companies confirmed that they have been carrying out various activities and applications in order to protect the environment. One of these companies stated that it produces own electric power through own hydroelectric power plant. Another company calculates the carbon footprint of all activities involved in the production and also administrative areas. The reason behind this act is to reduce their emissions within the scope of their fight against climate change. Apart from this, the most common practice in companies, in this context, is measuring the amount of water used and making efforts to reduce the amount of it. Converting all of the lights to the led system in order to reduce the amount of energy consumed in the lighting also reflects another example in common. The recycling and re-usage of the wastes generated from the daily activities of the employees can be shown as another application.

\section{German case}

Until now, according to German companies, safety of the employees always comes first. All production sites are run based on European safety standards. Then they of course take measures under the title of being green. For instance, using of recycled material, collecting all the wastes in a daily base and etc. They added as the common answer that if you do not recycle the wastes in a daily or weekly base, the general cost of these activities would be higher at the end. They also split up their daily wastes as plastics, papers, glass... from production, warehouse, and daily activities to use them for recycling. As mentioned before, one of them gave as an example that they use big windows to exploit natural heating energy to heat the company with less electric energy.

\section{General Precautions for Environment}

\section{Turkish case}

Each company has some precautions which have been put into practice according to companies' own principles to protect the environment. For instance the cardboard boxes which used for transporting the products. The cardboards are supported for being more stable to use them longer. In this way both the operational costs and the amount of the waste generated are reduced.

The waste of the cardboard boxes and plastic packaging materials are collected and delivered to the licensed companies which collect the wastes and disposal. Also the wastes generated in the company are also classified and send for recycling. In addition, most of the companies force both the customers and the employees to use biodegradable plastic bags.

Another company which is also very active in retail activities started a recall for the apparel products which are not used any more for recycling. In this context, it has been emphasized that the unused apparel products can be utilized by reusing or recycling and at the same time, the future waste can be reduced.

Another company which has ISO 14001 environmental management system certificates was steer to new sustainable production methods and product development which is environment friendly. In these new product development projects, the consumption of the water and energy resources is measured in consideration of environment and human health. In this way, the use of resources such as water, electricity and natural gases can be decreased and the wastes that are generated as a result of the production can be minimized.

German case

Actually companies are very careful about the universe. It could be true that money has the priority like in every business which runs after some profit but companies are also very keen on environment. It is obvious that they have to take some precautions against the environmental effects of their business because of the laws and other regulations. Accordingly, they obey these laws and have some precautions.

As the precautions, for instance; they use recycling bins for all their waste, for example; fluorescent light bulbs, fabric wastes, plastic wastes and waste papers. They collect these materials in every department for recycling. Recycling provides on the one hand getting rid of the wastes from the company and also from environment; on the other hand these materials cost with a cheaper price. The easiest example, also they gave this example, is plastic hangers, because as everybody knows in the apparel industry, a lot of hangers are needed to protect the shape of the products well. So, the hangers which are made of recycled material, as the first reason the companies get these hangers cheaper and secondly they are produced with less emitted $\mathrm{CO}_{2}$. 


\section{Supplier Selection and Environment}

Turkish case

According to the interviews, it is very important for the rest of the companies, while this situation is not a very important issue for one of the companies. With regard to the general judgement of all company managers, except one of them, they select their suppliers in accordance with the criteria determined by the companies' previous experiences. The environment oriented selection of the suppliers becomes one of the most indispensable criteria. The criteria that the suppliers are expected to fulfil can be listed as follows: Conformity with laws and regulations, no child labor, non-discrimination, balanced wage system and social rights, the conditions related to the working hours, healthy and safe working conditions and protection of the environment (HSE).

German case

There is a common idea that "environmental policy of suppliers' government/country is of course important to consider". Some of the companies also have some code of conducts to select their supplier/producer. There is a further answer that, European companies with European suppliers/producers do not think about the policy because they all have the same regulation. But the main company may request the fulfilment of requirements in the written and signed form from the supplier/producer.

If the producers/suppliers are not in Europe, they request some certificates but how they get the certificate and what are the terms and conditions to get it are also important.

\section{Enough Governmental Inducements/Obligations \\ Turkish case}

Although in Turkey "green logistics" is not yet made mandatory by laws and regulations, this concept is on the agenda of the sector. In Turkey some fines are applied when the carbon footprint limit of the companies is exceeded. Furthermore, the regulation on following up the greenhouse gases emissions was brought into force in 2019. It has been determined in the regulation that all the emissions will be monitored in the businesses according to the scope of the activity. For that reason, most of the companies make their own carbon footprint measurements in Turkey. German case

There are certainly both inducements and obligations for companies not to harm environment. The general idea which is understood during the interviews is the obligations and also some inducements for environment and environmental activities have beyond measure importance and these rules or obligations are indispensable for the managers. Managers believe that owing to these obligations and inducements, companies regulate their business activities by the thinking of environment. They also think that sometimes government sets up some rules which are not very logical and companies are not sure whether these rules help to improve environmental effect of companies activities or not. Nevertheless, they are happy that the governments are very keen on protecting the environment and they also think that the
European Union has one of the strictest rules in the world.

\section{Logistics \& Environment}

Turkish case

The common answer from companies about the importance of the logistics activities among other departments in terms of environment; the important point for the companies are human right, labor standards, environment, fight against corruption. That is why, all the activities about environment are carried out considering all the departments.

All the companies think that logistics activities have a negative impact on the environment. For that reason the vast majority of companies follow the carbon footprints including all logistics activities. However this is not just for a measurement of logistics activities. Companies carry out various sustainability projects in order to reduce the carbon emissions year by year. One of the companies also monitors the fuel consumption of each vehicle belonging to the company to determine the carbon emission rate on a yearly base.

One of the companies replied negatively and the rest of them think that they have a productive logistics management system because of the follow-up the carbon footprint about the question of the productive logistical management system by the ecological point of view. One of the companies supported the having an efficient logistic management system with ISO 14001:2004 Environmental Management Systems Certificate, ISO 50001 Energy Management Systems Certificate and Global Recycling Standard certificates that the company has.

It has been understood that the companies have a general code of conducts. There are categorized generally; social performance (such as human rights, employee safety), environmental performance (such as energy and water efficiency), supply chain performance, product and production performance, social responsibility performance. According to the answers, the logistic activities counted in the environmental performance. However, none of these companies have a logistic-wise code of conduct until now.

\section{German case}

The general idea about the logistics is that when companies have the environmental glasses on, only focusing on logistics is not enough to be green. Supply chain has much more importance than logistics. According to this manager being green of anything is to save resources as the best way or also it can be said that to get rid of the unnecessary processes. It means the elimination. After the elimination, managers can organize the remaining processes easily and more productively. So they will be green as a result automatically. It means to be green is the end of the processes not the beginning. The meaning of this conversation about the question; supply chain is more important. It is obvious that to be green is an achievement at the end of an efficient supply chain. 
The general idea about the environmental effect of logistics, it is huge but if it is compared with the other departments (production, sourcing...) it is low.

Companies answered the question about productive logistics management system in common that there are not many companies in the clothing industry performing an environmental management system. Also it is common for them not to think that their companies have the productive environmental logistics management system. But just one company indicated that they have very productive logistics management system by the ecological point of view, not in the German part of their business but they have it in the USA and in the UK part. To get positive response from the environment, they optimized their transportation routes, calculated the quantity of the liter of petrol consumed and carbon footprints of the activities and so on.

About the code of conduct question, companies stated that they do not have any written "Code of Conduct" on logistics. But they try to organize their activities as sufficient as possible and not to harm the environment.

\section{RESULTS}

Within the scope of this study, logistic activities of the companies operating in Turkish and German textile sector were compared under the environmental title. Logistics, in the concept of fast fashion is an important term with variety of applications in order to reduce the cost and improve the value on the products. However, logistic activities also have an impact on the environment like every other activity in the companies.

In this study, the applications about the logistics were compared through the answers received by Turkish and German textile companies. So the opinions about the answers are shown below.

- Green perspective and the industry: While the practices in two countries are similar, the environmental sensitivity of the sector is supported by various environmental legislations.

- Money or environment or both: While Turkish companies consider the environment and the money as a minority, they mostly consider the environment theoretically, but in practice they are very weak. German companies on the other hand, approach this issue more rationally. They consider both the environment and the money together theoretically and practically supporting with the environmental certificates.

- Until now...: Turkish and German companies seem to have done as much study on environment as until now. These studies are mostly focused on production. Such as measuring and following the carbon footprints, separating and sending to recycle the wastes generated in companies day-by-day, using recycled materials as much as possible. As a matter of fact, German companies are very careful to take various precautions considering the health of the employees at the focus of all the work done. It is necessary to point out that a Turkish company established its own hydroelectric power plant in order to provide own electric energy which cannot be ignored as a study done for the environment.

- General Precautions for Environment: Both Turkish and German companies take various precautions to protect the environment. Such as, using recycled materials, modifying the materials to use for a longer time, carrying out various projects supported by environmental laws.

- Supplier Selection and Environment: Both Turkish and German companies consider the environment when choosing suppliers. However, the price offered by the supplier is in front of the environment for Turkish companies. This situation is mostly in the direction of environment for German companies.

- Enough Governmental Inducements/Obligations: "Green logistics" in Turkey is a slightly newer concept than Germany. Within this context, the carbon footprint boundaries of companies are followed in Turkey. However, in Germany there are many applications on "green logistics". Some of those; selection of the transport type, regulation of the transport time, road optimization, following the occupancy rate of the vehicle, considering the age of the vehicle and the type of the fuel, carbon footprint of the vehicle and so on. Accordingly, it can be said that German government has a tighter control mechanism then Turkey.

- Logistics \& Environment: Both Turkish and German companies are convinced that logistic activities effect the environment negatively. While few Turkish companies are involved in carrying out various projects to overcome this negative effect, all German companies have undertaken various studies keeping the governmental auditing in this regards. Both companies are convinced that focusing on logistics alone should not be sufficient in terms of environmental conscience. The important thing in this regard is that focusing on the supply chain from the very beginning to the end.

Logistics is a concept that provides added value on products and decreasing the expenditures. Particularly within the context of logistic activities, countries that have a geographical advantage can further increase the benefits that they provide from the logistic activities. In addition to the benefits provided by logistics activities, there are also some environmental threats.

Conducted examinations and the information based on the activities of the two countries' companies show that the activities carried out by the companies in Turkey in order to minimize the damaging effect of logistics are more inadequate than the ones in Germany. When the governments are compared in the same direction, it will be seen that the compulsory conditions of the statutory audits are performed more imperatively by German government than Turkish government. Turkish government should increase the inspections about the environment to industrial enterprises or resettle such as additional taxes and so on. Turkey became a party to the UN Framework Convention on Climate Change (UNFCCC) on 24 May 2004 and the Kyoto Protocol on 26 August 2009. So Turkey needs to apply more 
environmentally friendly strategies both in accordance with the UNFCCC and the Kyoto Protocol.

By closing the gap between the countries, not only governments but also companies need to take precautions to at least reduce the carbon emissions [16]. In this context, the auditing on carbon emissions can be increased and some more taxes can be applied. In addition, in order to solve the problems related to logistics, necessary legal arrangements should be made about the sector and a significant control mechanism should be developed together with standards.

In order to benefit more from the geographical superiority as a country which is surrounded on three sides by the sea needs to have better sectoral infrastructure. At the same time, the problems should be solved in areas such as the situation of the ports combined transportation possibilities, balance between transport modes and their competences, qualified human capital, technology, know-how and legal regulations.

The need of qualified personnel should be resolved to give more importance to the colleges and universities which provide training on logistics in Turkey. In this context, the curricula of colleges and universities offering logistics should be rearranged to follow the developments around the world.

The scope of the concept of green logistics can be expanded with further studies by using this study. For instance, it will be possible to contribute to the literature by analyzing the application of different sectors from different countries.

\title{
REFERENCES
}

[1] Wittenbrink, P., Transportmanagement - Kostenoptimierung, Green Logistics und Herausforderungen an der Shcnittstelle Rampe, Aufl. Springer Gabler, Springer Fachmedien Wiesbaden, 2014, 322

[2] McKinnon, A., Cullinane, S., Browne, M., Whiteing, A., Green Logistics-Improving the environmtental sustainability of logistics, Great Britain: Kogan Page, 2010

[3] Küçük, M., Logistics in the Fashion and Fashion Retail Industry in Europe Under Consideration Of Sustainability Aspects (Green Logistics), M.Sc. Thesis, Faculty of Textile and Clothing Technology Hochschule NiederrheinUniversity of Applied Sciences, Mönchengladbach, 2012

[4] Christopher, M., Peck, H., Managing Logistics in Fashion Markets, In: International Journal of Logistics Management, 1997, 8, 2, 63-74

[5] Sarkar, A.N., Green Supply Chain Management: A Potent Tool for Sustainable Green Marketing, In: Asia-Pacific Journal of Management Research and Innovation, 2012, 8, 4, 491-507

[6] Perera, P.S.T., Perera, H.S.C., Wijesinghe, T.M., Environmental Performance Evaluation in Supply Chain, In: Vision, 2013, 17, 1, 53-61

[7] Batra, S., Chanana, B., Greening the Supply Chain: A Way towards a New Way, In: International Journal of Business Quantitative Economics and Applied Management Research, 2015, 2, 3, 23-31

[8] Abdullah, R., Daud, M., Ahmad, F., Shukti, A.A., Green Logistics Adoption among 3PL Companies, In: International Journal of Supply Chain Management, 2016, 5, 3, 82-85

[9] Desore, A., Narula, S.A., An overview on corporate response towards sustainability issues in textile industry, In: Environ Dev Sustain, 2018, 20, 1439-1459, https://doi.org/10.1007/s10668-017-9949-1

[10] Gardas, B.B., Raut, R.D., Narkhede B., Modelling the challenges to sustainability in the textile and apparel (T\&A) sector: A Delphi-DEMATEL approach, In: Sustainable Production and Consumption, 2018, 15, 96-108

[11] Samar Ali, S., Kaur, R., Ersöz, F., Lotero et al., Evaluation of the effectiveness of green practices in manufacturing sector using CHAID analysis, In: Jnl Remanufactur, 2019, 9, 3-27, https://doi.org/10.1007/s13243-018-0053-y

[12] World Bank, 2018, Available at: https://lpi.worldbank.org/international/global [Accessed on January 2019]

[13] Kawamura, Y., Doing Research in Fashion and Dress. An Introduction to Qualitative Methods, United Kingdom: Berg Publishers, 2011

[14] Given, L.M., The Sage Encyclopedia of Qualitative Research Methods, Sage: Thousand Oaks, CA, 2008, 2, 697-698, Available at: http://www.sfu.ca/ palys/Purposive\%20sampling.pdf [Accessed on January 2019]

[15] Mack, N., Woodsong, C., MacQueen, K.M., Guest, G., Namey, E., Qualitative Research Methods: A Data Collector's Field Guide, 2005, Available at: http://pdf.usaid.gov/pdf_docs/PNADK310.pdf [Accessed on January 2019]

[16] M\&S greenhouse emissions and climate change performance, Available at: https://corporate.marksandspencer .com/documents/plan-a-our-approach/mns-greenhouse-emissions-and-climate-change-performance-report.pdf [Accessed on January 2019]

\author{
Authors: \\ MEHMET KÜÇÜK ${ }^{1}$, MARCUS O. WEBER², CLAUS BÜHS ${ }^{2}$, MARKUS MUSCHKIET² \\ ${ }^{1}$ Ege University, Engineering Faculty, Textile Engineering Department, Turkey \\ ${ }^{2}$ Niederrhein University of Applied Sciences, Faculty of Textile and Clothing Technology, Germany
}

\section{Corresponding author:}

MARCUS O.WEBER

e-mail: marcus.weber@hs-niederrhein.de 